Joulonal of Physical Education (JoulPE)
Vol. 1, No. 2, December 2020, Hal 10-13
E-ISSN: 2723-4746

\title{
TINGKAT MOTIVASI LATIHAN UKM PANAHAN TEKNOKRAT SELAMA PANDEMI COVID
}

\author{
Ihsanudin ${ }^{1}$, Aditya Gumantan ${ }^{2}$ \\ Universitas Teknokrat Indonesia, ${ }^{1,2}$ \\ Ichsanoedin31@gmail.com ${ }^{1}$ \\ Aditya.gumantan@teknokrat.ac.id ${ }^{2}$
}

\begin{abstract}
Received: 6 Desember 2020
Accepted: 17 Desember 2020

Abstract

Training activity is related to an achievement which cannot be separated from many factors and one of them is training motivation. The level of motivation possessed by the members of the Archery UKM at the University of Teknorat Indonesia has not been clearly described during the Covid-19 pandemic. With the aim of this study is to determine the level of motivation for training in Archery UKM This research is a descriptive study using the analytical survey method. The subject of this research is the Archery UKM of Technorat University of Indonesia, with a total of 15 members. The data collection technique in this study used an instrument in the form of a questionnaire. The data analysis technique used in this research is descriptive statistical analysis with proportions. The results showed that the level of motivation to exercise was $87.77 \%$, which was divided into $53.33 \%$ intrinsic factors and $46.66 \%$ extrinsic factors. Likewise, the results of training motivation during the Covid-19 pandemic for Archery UKM Members can be classified as high.
\end{abstract}

Published : 29 Desember 2020

Keywords: Archery, Motivation, Pandemic

\begin{abstract}
Abstrak
Aktivitas latihan berkaitan dengan pencapaian sebuah prestasi yang tidak akan lepas dari banyak faktor dan satu diantaranya yakni motivasi latihan. Tingkat motivasi yang dimiliki oleh anggota UKM Panahan Universitas Teknorat Indonesia belum secara jelas digambarkan selama pandemi covid-19. Dengan tujuan dari penelitian ini adalah untuk mengetahui Tingkat motivasi latihan UKM Panahan. Penelitian ini adalah penelitian deskriptif yang menggunakan metode survey analisis. Subyek dari penelitian ini adalah UKM Panahan Universitas Teknorat Indonesia, dengan jumlah 15 anggota. Teknik pengambilan data pada penelitian ini menggunakan instrumen berupa angket Teknik analisis data yang digunakan dalam penelitian ini adalah analisis statistik deskriptif dengan persentase. Dari Hasil penelitian, menunjukkan Tingkat motivasi latihan sebesar 87,77\%, yang dibagi menjadi faktor instrinsik sebesar 53,33\% dan faktor ekstrinsik sebesar 46,66 \%. Demikian, dengan hasil dari motivasi latihan selama pandemi covid-19 pada Anggota UKM Panahan dapat di klasifikasikan tinggi.
\end{abstract}

Kata Kunci: Panahan, Motivasi, Pandemi

To cite this article:

Ichsanudin \& Gumantan, Aditya. (2020). Tingkat Motivasi Latihan Ukm Panahan Teknokrat Selama Pandemi Covid . Journal of Physical Education. Vol 1, No (2), Hal 10-13

\section{PENDAHULUAN}

Mencapai prestasi, khususnya olahraga seorang atlet harus mendorong motivasi dari dalam diri untuk dijadikan sebagai kekuatan, dorongan, dan semangat, psikologisnya. Sebelum seseorang dapat mewujudkan keinginannya untuk berprestasi maka sudah seharusnya seseorang itu memiliki motivasi yang kuat agar ketika dalam menjalani prosesnya dapat berjalan dengan benar dan baik. Ditambahkan (Winardi, 2002) bahwa motivasi adalah proses bagian internal maupun bagian eksternal setiap individu dalam menimbulkan serta memunculkan sikap 
dan sifat antusiasme dalam mengerjakan hal apapun. Seseorang akan terdorong untuk melakukan hal dan sesuatu apabila terdapat kebutuhan tertentu (Juliyandi, Saifuddin, \& Abdurrahman, 2015). Dari penjabaran diatas penting sekali bagi seeoragn dalam hal mempunyai sebuah motivasi untuk dapat mencapai apa yang akan dikehendaki. Sebelum melaksanakan latihan, motivasi adalah hal lainnya yang harus dimiliki seorang atlet.

Latihan merupakan faktor yang sangat mendasar dalam mencapai puncak penampilan pada kegiatan olahraga, khususnya olahraga prestasi. Kegiatan aktivitas fisik untuk orang normal betujuan guna meningkatkan kesegaran dan ketahanan fisiknya (Siswanto, 2014). Untuk orang normal yang bukan seorang olahragawan kegiatan aktivitas fisik bukan merupakan suatu tuntutan wajib yang harus dilakukan. tujuan lain aktivitas olahraganya hanya untuk meningkatkan kualitas hidup untuk seseorang tersebut (Siswanto, 2014). Seperti melakukan kegiatan olahraga aerobik. Aktivitas olahraga aerobik ini biasanya merupakan aktivitas olahraga dengan intensitas denyut rendah-sedang yang ddilakukan secara terus -menerus dengan tempo waktu yang cukup lama, seperti: jalan kaki, bersepeda, dan jogging (Palar, Wongkar, \& Ticoalu, 2015).

Sementara bagi seorang atlet, latihan menjadi kewajiban utama sebagai modal awal dalam prestasi.Dengan menjalani latihan dalam meningkatkan performa mendapatkan performa yang bagus latihan dengan keras dan disiplin menentukan hasil yang baik, khususnya dalam latihan fisik. Yang dimaksud latihan fisik yang terprogram adalah bentuk latihan fisik yang dilakukan dengan teratur terdapat intensitas, frekuensi, serta durasi dan memiliki tujuan tertentu (Uliyandari, 2009). Pada saat bertanding penampilan dan performa seorang atlet itu sendiri bisa terlihat jelas dari keras dan disiplinnya atlet tersebut saat berlatih. Dengan menambahkan dan melakukan latihan bertujuan untuk meningkatkan fungsi dan mempersiapkan otot untuk melakukan aktifitas fisik. Selain, Berkaitan dengan pertumbuhan fisik tersebut, latihan dapat membentuk tubuh yang menarik dan juga pasti didam-idamkan oleh hampir setiap orang . model latihan akan memberikan damak secara spesifik pada fisiologi dan bentuk tubuh (Parahita, 2009).

Ketika seorang atlet akan melakukan suatu pertandingan pastinya ia melakukan latihan yang intensif dan terstruktur terlebih dahulu agar tidak terjadi cedera akibat fungsi dan kesiapan otot tidak maksimal. Sebuah program latihan yang baik harus dimulai dari intensitas rendah kemudian bertahap naik ditingkatkan ke tinggi agar atlet dapat adaptasi (Parahita, 2009). Misalkan bentuk latihan untuk daya tahan, durasi selama latihan sebaiknya berkisar waktu 40-45 menit di dalam target latihan supaya mendapatkan perbaikan daya tahan (Uliyandari, 2009). Durasi latihan berhubungan dengan intensitas latihan. Latihan menggunakan intensitas tinggi dilakukan dalam jangka waktu yang lebih singkat, begitu juga sebaliknya (Parahita, 2009). Begitu juga dengan bagusnya performa ketika bertanding itu akan berbanding lurus dengan kerja keras serta disiplin dalam menjalani proses latihan. Dengan latihan tidak hanya proses luar tubuh yang terbentuk tetapi juga proses dalam tubuh, seperti sistem kardiovaskuler. Laju dan pacu detak jantung ketika seseorang beristirahat lebih rendah daripada laju dan pacu detak jantung ketika melakukan latihan fisik (Harsono, Liman, \& Djohan, 2012).

Pada penghujung tahun 2019 bumi kita digegerkan dengan penemuan sekaligus wabah baru yaitu virus covid-19. Awalnya abah ini menjangkit masyarakat yang ada diwuhan, China. Namun dengan begitu cepatnya virus ini menyebar dan menular akhirnya pada 11 Maret 2020 World Health Organization (WHO) mengumumkan bahwa Covid-19 dinyatakan sebagai pandemi. UNESCO sebagai organisasi yang bergerak dibidang pendidikan mengatakan akibat penutupan sekolah dan wabah ini 300 juta murid terganggu kegiatan belajarnya. Covid-19 memukul semua lapisan masyarakat didunia tidak hanya lingkungan pendidikan saja semua terkena dampak dari pandemi ini yang mengakibatkan terhentinya segala aktifitas apapun. Tidak hanya perkuliahan yang terhenti proses latihan dari dari unit kegiatan kemahasiswaan turut terhenti. Unit kegiatan mahasiswa panahan merupakan salah satu bagian ukm yang terhenti sementara kegiatannya. Namun setelah penerapan new normal dan physical distancing yang digalakkan oleh pemerintah, aktivitas latihan sudah dapat aktif kembali. Aktivitasa latihan dilakukan dengan mengikuti protokol kesehatan yang sudah ditetapkan oelh pemerintah. Dari pihak kampus sendiri juga mempunyai protokol wajib yang harus di ikuti semua anggota ukm dalam menjalani kegiatan latihan. Ketika penetapan physical distancing, tidak hanya mengganggu aktivitas fisik, namun juga secara tidak langusng mengganggu motivasi latihan. Penelitian ini akan berfokus pada motivasi latihan selama penerapan physcical distancing saat pandemi covid-1. 


\section{METODE PENELITIAN}

Penelitian ini adalah penelitian deskriptif dengan menggunakan metode survei. Adapun teknik pengumpulan datanya menggunakan angket. Ciri khas metode survei adalah data dikumpulkan dari responden dengan menggunakan kuisioner dengan pendekatan formal (Suharsimi Arikunto). Kuisioner merupakan salah satu ciri dari suatu penelitian deskriptif yang mengumpulkan dan mencatat data yang diperoleh dari angket yang telah diisi oleh atlet Unit Kegiatan Mahasiswa.

Sample dan populasi penelitian adalah semua anggota UKM panahan yang berjumlah 15 orang Mahasiswa.

\section{HASIL DAN PEMBAHASAN}

Table 1. Tingkat Motivasi Latihan

\begin{tabular}{lcclll}
\multicolumn{5}{c}{ Table 1. Tingkat Motivasi Latihan } & \\
\hline $\begin{array}{l}\text { Faktor } \\
\text { motivasi }\end{array}$ & $\begin{array}{l}\text { Jum } \\
\text { lah }\end{array}$ & $\begin{array}{l}\text { Skor } \\
\text { Angket }\end{array}$ & $\begin{array}{l}\text { Skor } \\
\text { Angket } \\
\text { max }\end{array}$ & $\begin{array}{l}\text { Persenta } \\
\text { se }\end{array}$ & Klasifikasi \\
\hline $\begin{array}{l}\text { Faktor } \\
\text { Intrinsik }\end{array}$ & 8 & 110 & 150 & $53,33 \%$ & Cukup \\
\hline $\begin{array}{l}\text { Faktor } \\
\text { Ekstrinsik }\end{array}$ & 7 & 285 & 350 & $46,66 \%$ & Cukup \\
\hline Total & 15 & 395 & 450 & $87,77 \%$ & Tinggi \\
\hline
\end{tabular}

Berdasarkan Hasil analisis data tingkat motivasi latihan dari anggota UKM Panahan diperoleh data presentase pada faktor Instrinsik sebesar 53,33\% yang dimasuk kedalam klasifikasi cukup dan persentase faktor Ekstrinsik sebesar 46,66\% yang masuk kedalam klasifikasi cukup. Berdasarkan dari data hasil penghitungan presentase diatas, motivasi latihan dari faktor intrinsik lebih besar dari faktor Enstrinsik. Sehingga dapat dikatakan motibasi latihan dari faktor intrinsik yang berpengaruh dan paling dominan. Secara keseluruhan hasil dari presentase motivasi latihan anggota UKM Panahan dari 15 Anggota Mahasiswa adalah Sebesar 87,77 \% dimasukan ke klasfifikasi Tinggi.

Faktor Ekstrinsik Latihan adalah sebuah faktor motivasi yang berasal dari luar seseorang. Terdapat riga indikator kondisi lingkungan, unsur dinamis seseorang, dan Upaya dalam pembelajaran. Indikator yang pertama berasal Kondisi lingkungan dari anggota ukm, yang berupa faktor keadaan akan alam, lingkungan tempat tinggal masing masing anggota, pergaulan dengan rekan, serta kehidupan bermasyarakat juga turut andil mendukung adanya semangat didalam suatu proses baik belajar maupun latihan. Yang kedua melalui unsur-unsur dinamis dalam suatu proses latihan dan belajar, yakni dimana setiap anggota memiliki sebuah perasaan, kemauan, ingatan serta pikiran yang pastinya akan mengalami perubahan yang berasal dari sebuah pengalaman hidup dan serta tentunya ada seorang pelatih yang baik dalam membimbing, dan itu semua merupakan kondisi yang bagus bagi seoraang atlet. Indikator terakhir didalam faktor ekstinsik merupakan bentuk dari sebuah artisipasi serta teladan dalam memilih perilaku yang baik dan benar dan sudah merupakan upaya dari seorang pelatih dalam memberikan pelatihan dan pengajaran. Khususnya dalam latihan rutin yang tentunya akan memberikan dampak dan pengaruh besar dari perkembangan seorang atlet.

Faktor Instriksik adalah faktor yang berasal dari dalam diri seseorang. Ada tiga indikator yang terdapat didalam faktor instrinsik yakni Cita-cita/Aspirasi, kemampuan dan kondisi jasmani rohani. Indikator citacita menggambarkan para anggota yang dimana dia memahami cita-cita atau aspirasi dari dalam dirinya akan mampu memahami serta mengerti apa yang menjadi tujuan dalam latihan dan juga bisa mewujudkan serta aktualisasi dirinya disaat menjalani latihan. Penunjang indikator cita-cita/aspirasi dari anggota perlu sebuah ungan dari kemampuan atau keterampilan anggota itu sendiri. Setiap anggota UKM harus memiliki sebuah kecakapan dan sebuah keterampilan untuk menguasai materi latihan agar kemudian dapat menerapkan dan mengembangkannya pada prestasi. Indikator terakhir yakni kondisi dari setiap masing-masing anggota UKM akan sangat berpengaruh pada motivasi latihan mereka, baik itu kondisi secara jasmani maupun kondisi secara rohani. Anggota UKM yang latihan dalam keadaan tubuh sehat jasmani dan rohaninya akan menunjukkan motivasi intrinsik yang bisa dibilang tinggi, di mana setiap anggota tersebut akan bersemangat dalam menjalani latihan. Hal tersebut tentunya akan berbanding terbalik jika anggota mengalami sakit secara fisik atau ketika 
sedang menghadapi sebuah masalah rumit, maka anggota tersebut pasti tidak sedang lama kondisi semangat dalam latihan.

\section{SIMPULAN}

Terdapat pengaruh motivasi intrinsik terhadap latihan dari semua anggota ukm panahan universitas teknokrat indonesia. Hal tersebut dapat dilihat pada presentase dari hasil angket yang sudah diberikan kepada anggota ukm, dengan persentase faktor instrinsik sebesar 53,33\% dengan kulaifikasi cukup. Hasil angket pada faktor ekstrinsik dengan hasil persentase sebesar 46,66 \% yang daapt dikualifikasikan cukup. Ini menandakan bahwa bahwa motivasi intrinsik mempengaruhi faktor latihan dari dalam diri anggota UKM dimana mempengaruhi dari aspirasi, kemampuan serta tingkat jasmani dan rohani dari masing-masing anggota ukm panahan.

\section{DAFTAR PUSTAKA}

Harsono, B., Liman, J., \& Djohan, N. (2012). Rancang bangun alat pemantau laju detak jantung saat latihan fisik. Jurnal Teknik dan Ilmu Komputer, 1(4), 338-346.

Juliyandi, J., Saifuddin, S., \& Abdurrahman, A. (2015). Hubungan Motivasi Belajar dengan Hasil Belajar Pendidikan Jasmani Olahraga dan Kesehatan pada Siswa SMP Negeri 1 Lhoksukon Aceh Utara Tahun Pelajaran 2012/2013. Jurnal Ilmiah Mahasiswa Pendidikan Jasmani, Kesehatan dan Rekreasi, 1(2).

Palar, C. M., Wongkar, D., \& Ticoalu, S. H. R. (2015). Manfaat latihan olahraga aerobik terhadap kebugaran fisik manusia. eBiomedik, 3(1).

Parahita, A. (2009). Pengaruh Latihan Fisik Terprogram Terhadap Daya Tahan Otot pada Siswi Sekolah Bola Voli Tugu Muda Semarang Usia 9-12 Tahun. Medical Faculty.

Siswanto, A. (2014). Hubungan Antara Latihan Fisik Dan Kapasitas Vital Paru Pada Siswa Pencak Silat Persaudaraan Setia Hati Terate Di Universitas Muhammadiyah Surakarta. Universitas Muhammadiyah Surakarta.

Uliyandari, A. (2009). Pengaruh latihan fisik terprogram terhadap perubahan nilai konsumsi oksigen maksimal (VO2Max) pada siswi sekolah bola voli tugu muda Semarang usia 11-13 tahun. Medical faculty.

Winardi, J. (2002). Motivasi dan pemotivasian dalam manajemen. Jakarta: PT. Raja Grafindo Persada.

\section{BIOGRAFI PENULIS}

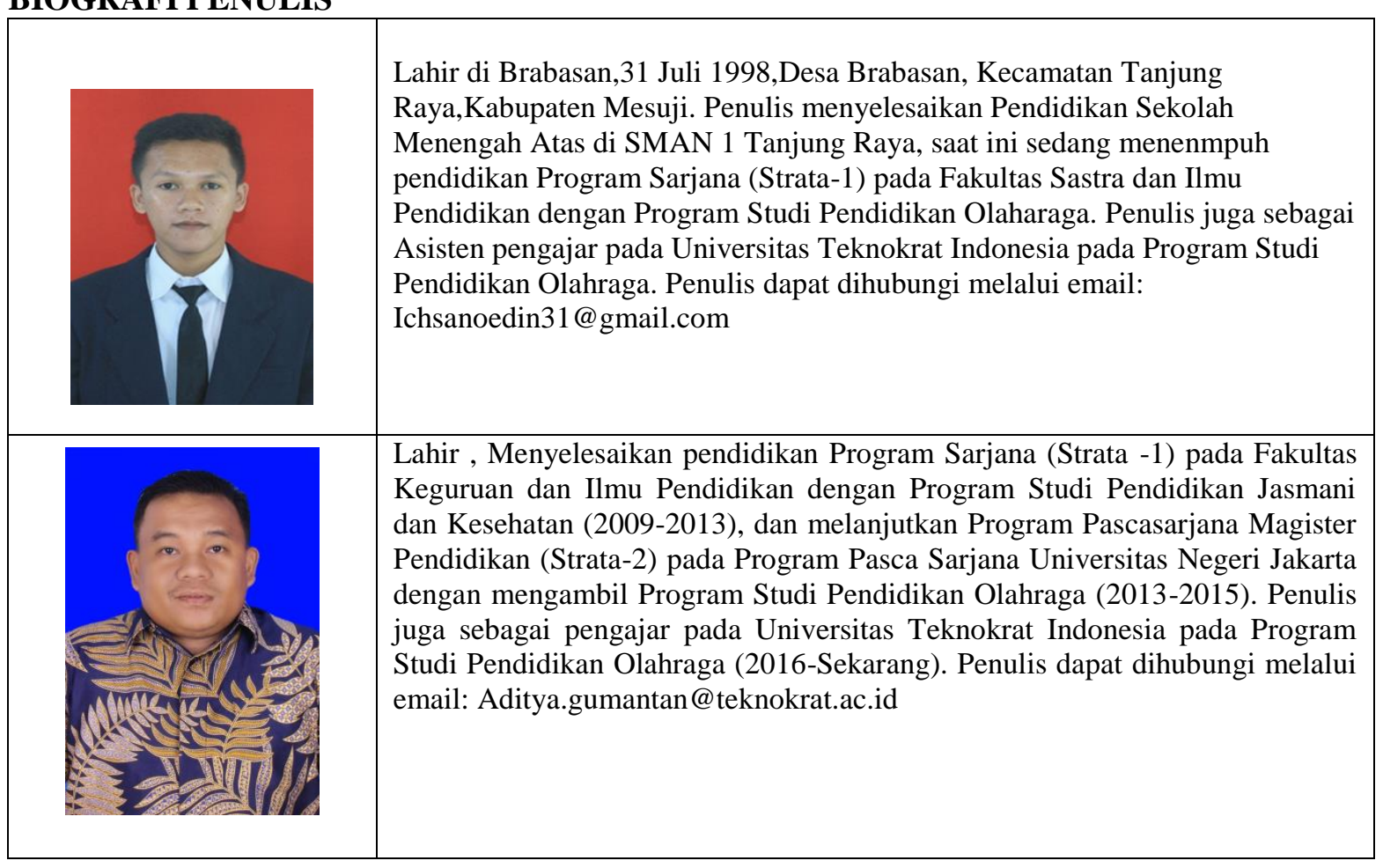

